\title{
Piercing the Corporate Boilerplate: Anti-Dilution Clauses in Convertible Securities
}

\author{
Stanley A. Kaplan
}

The convertible security ${ }^{1}$ has long been known in the United States as a useful financing device ${ }^{2}$ which the issuing corporation can sell at a higher price than nonconvertible securities because it gives the

Stanley A. Kaplan, Professor of Law, the University of Chicago Law School, is a member of the Illinois bar. He received a Bachelor of Philosophy degree in 1931 and a Doctor of Law degree in 1933 from the University of Chicago and a Master of Laws degree from Columbia University in 1934.

1 Throughout this article the term "convertible security" will be used to include, unless the context indicates otherwise, bonds, debentures and preferred shares which are entitled to conversion into the issuing company's common stock at the option of the holder. The common stock deliverable upon exercise of the right of conversion will be referred to as the "underlying security."

2 Convertible securities can, of course, have different characteristics. Securities can be convertible at the option of the issuer or upon the occurrence of certain events. The right of conversion can exist for the life of the convertible security or for shorter periods, either stipulated or contingent in length. The rate of conversion or the number of underlying securities deliverable upon exercise of conversion can be made variable either by the passage of time or by other contingencies. The convertible security may grant a right to convert into securities other than common stock or securities other than those issued by its original issuer, e.g., into securities of a subsidiary or of another company which has either granted the right of conversion or posted securities in escrow deliverable against conversion.

The device's flexibility may even permit upward conversion although the issuing company will probably be unable to effect upward conversion into debt securities unless it has the capital structure and required surplus which would allow it to buy common shares for cash. For example, preferred stock may be made convertible into common stock and also into debt securities. Upward conversion alone from common stock into 
purchaser the advantages of a prior claim on assets and earnings plus the option to convert his investment into common stock. ${ }^{3}$ For the right of conversion to be meaningful, the investor must be assured either that the amount and character of the security received upon conversion will remain stable or that adjustments will be made to protect his investment should the attributes of this underlying security be changed. To protect the convertible shareholder's interest against such changes in the underlying securities, "anti-dilution" clauses are generally included as a matter of course in modern convertible securities or in the charter or indenture creating them. ${ }^{4}$ In the absence of specific provi-

a class $\mathrm{A}$ common or a junior preferred stock has also been used where the latter is being sold to the public while the remaining common shares are held by the original stockholders. The financial position of the shares sold to the public is often buttressed by restricting dividends on the common shares for a stipulated period of time and by limiting the common shares' right of conversion into a parity position in accordance with a formula based either on time or demonstrated earnings. Another type of upward conversion was recently offered to holders of common shares in a large publicly held company. A proportion of its common was exchanged for newly created convertible preferred, convertible back into common; this enabled the company to create a widely held convertible preferred stock which could be used for purposes of corporate acquisition.

3 The convertible security probably attained its greatest popularity in this country following World War II when the changing value of the dollar and the concomitant fear of inflation made fixed-dollar securities generally less attractive. At the same time the flotation in increasing amounts of securities of new companies with relatively small equity cushions made a prior position, coupled with an option to acquire equity, a desirable if not essential sales feature. Jennings \& Marsh, Cases on Securties Regulation 371 (1963). In some instances the fear of infation was combatted by providing that evidences of indebtedness would be payable in amounts of currency which would be adjustable upwards in accordance with a cost-of-living index. A parallel movement in the insurance field eventuated in the variable annuity, which seeks to provide upward adjustment by a combination of common stock investment and insurance and by the varying of annuity payments in accordance with stock performance. On the business aspects of using convertible securities in the raising of capital, see generally PIlcher, Raising Capiral With Convertible Securties (1961). See also Deiving, Financial Policy of Corporations 256-75 (5th ed. 1953).

The convertible security is relatively new as an important financing device in the European market. See R. Jones, Hoogovens to Pechiney, Barron's Nat'l Bus. \& Financial Weekly, March 1, 1965, p. 5, col. 1, setting forth examples of convertible bond issues in Germany, Japan, the United Kingdom, France, Holland, Italy and Belgium. The writer comments:

The combination of fixed-interest security with a future call on the equity seems ideally suited to the present state of European capital markets. . . . It apparently is the answer to the dilemma of conservative Continental savers who find the interest rates attractive but traditionally shy away from equities. At the same time, stock market investors, made cautious by four years of profitless inflation, now can obtain position in blue-chips with some limit on the downside risk. Finally, the issuing companies are able to raise large sums at relatively reasonable interest costs, with a good chance of broadening their equity base without excessive dilution. Id. at p. 5, cols. 2-3.

See also The Convertible Bond Comes to Belgium, 17 WeEkLX BuLletrn of the KREDIETBANK OF BRUSSELS 261 (1962).

4 Loss suggests that in practice an anti-dilution provision has become necessary to the 
sions to protect against dilution, there is a great probability that narrow and literal interpretation of the contractual right to convert would limit the right to precisely what was specified, without adjustment for subsequent substantial changes in the attributes of the underlying security. ${ }^{5}$

All too often, however, the anti-dilution clause has been viewed by attorneys and investment bankers as "boilerplate," a standard provision not subject to, or worthy of, negotiation. For instance, the usual prospectus describing securities for sale in a public offering registered under the Securities Act of 1933 contains language referring to the antidilution clause in substantially the following nebulous terms: "The securities contain provisions for adjustments in the right of conversion upon the occurrence of certain contingencies." $\mathrm{I}$ have seen attorneys prepare convertible securities by cutting anti-dilution clauses from instruments of other companies and pasting them into the instruments being prepared, changing only the number of shares involved and the name of the securities to be issued. In many instances the issuer's attorney ignores the fact that clauses taken from other instruments may have been carefully designed to protect the senior security's right of conversion and by using these clauses concedes many legitimate arguments which could be made for conversion provisions more favorable to the holders of underlying securities. ${ }^{7}$

Customary anti-dilution clauses are long and complex, presenting intricate problems of draftsmanship which may often deter penetrating examination. But the frequent failure to consider anti-dilution clauses

marketing of convertible securities: "Indeed, the preferred [in Park \& Tilford, Inc. v. Schulte, 160 F.2d 984 (2d Cir.), cert. denied, 332 U.S. 761 (1947)] was not even genuinely convertible, in the sense that the convertibility privilege was not protected against dilution of the common through stock dividends or splits." 2 Loss, SEcurimes Regulatron 1067 (2d ed. 1961).

5 See Parkinson v. West End Street Ry., 173 Mass. 446, 53 N.E. 891 (1899).

b A typical prospectus issued in 1962 described conversion rights in toto as follows:

Conversion Rights

The Debentures are convertible at the option of the holders at any time after January 1,1963 , and to and including July 15, 1972, into Common Stock of the Company at the conversion prices set forth on the cover page of this prospectus. The conversion prices are subject to adjustment in certain events to prevent dilution. Upon conversion, no adjustment will be made for interest or dividends. Fractions of shares resulting from conversion will be paid in cash. Conversion rights of Debentures called for redemption expire at the close of business on redemption date.

Copy on file in The University of Chicago Law Review office.

7 The interests of the holders of a convertible security will in many respects necessarily be in direct opposition to those of the holders of the underlying securities. Every advantage granted to the convertible security holders through the anti-dilution clause diminishes the interests of the holders of underlying securities; conversely, any failure of the anti-dilution clause to protect against diminution of the value of the conversion privilege will dilute the value of the senior securities. 
for possible disadvantages to the convertible security holders and conversely for their effects on the underlying security holders means that bargains are often made upon uninformed assumptions. ${ }^{8}$ Draftsmen of anti-dilution clauses should be cognizant of the different solutions which are available and of the significant variations in the rights of the convertible security holder which result. They should not assume that protection against dilution is too complex a problem to bear re-examination or that the anti-dilution clauses must be so neutral that they benefit neither the convertible security holder nor the common shareholder. ${ }^{9}$

\section{Anti-Dilution Clauses in Operation}

To draft an anti-dilution clause the lawyer must determine the degree of protection the investor seeks in a number of recurrent situations: share splits or combinations, ${ }^{10}$ sales of common stock below the specified

8 It should be noted that anti-dilution clauses may also be employed in stock warrants, stock rights, and options to purchase stock. However, the elaborate clauses which are standard in convertible securities are seldom used in other instruments. The stock right, which usually lasts for only two or three weeks, may not even contain any anti-dilution provision because of the improbability of change within such a short period of time; in a random group of stock rights there was no anti-dilution provision. The long-term warrant to purchase stock, on the other hand, usually contains some provision protecting against dilution. A random group of stock purchase warrants handled the situation by various devices such as: (a) the issuance of the warrants pursuant to, and incorporating by reference, a Warrant Agency Agreement which contains a full anti-dilution clause similar to a debenture indenture; (b) a reference on the facing sheet of the warrant indicating that the number of kinds of securities deliverable or the exercise price may be altered pursuant to conditions stated on the reverse side of the warrant; and (c) an abbreviated generalized anti-dilution clause. A long-term stock option also generally contains an anti-dilution clause, which may vary from the general provision used in stock warrants to the elaborate standard anti-dilution clause depending upon the length of time for which and the person to whom the option is granted. An agreement to purchase stock for delivery at a future date may contain a provision that there will be no change in the capital structure of the company in the interim when the stock is purchased directly from the issuer or a short general anti-dilution clause when it is purchased from someone who is not in control of the corporation. But often such an instrument does not deal with this contingency at all, in which case the purchaser takes a serious risk that the nature of the stock or of the corporate structure of the issuer will change during the interval between the date of his contract and the date of actual delivery.

9 See, for pioneering work in this area, BERLE, STUdY IN THE LAw of Corporation FINANCE $\mathrm{ch}$. VII (1928). The most comprehensive treatment of convertible securities and of anti-dilution clauses in the legal periodicals is Hills, Convertible Securities-Legal Aspects in Draftsmanship, 19 CALIF. L. REv. I (1930). A shorter but excellent consideration of convertibility is contained in Buxbaum, Preferred Stock-Law and Draftsmanship, 42 Calif. L. Rev. 243 (1954). See also Graham, Dodd \& Cottle, Security Analysis 615-19 (4th ed. 1962); Fleisher \& Cary, Taxation of Convertible Bonds and Stock, 74 HARv. L. Rev. 473 (1961); Irvine, Some Comments Regarding "Anti-dilution" Provisions Applicable to Convertible Securities, 13 Bus. LAw. 729 (1958); Keith, Convertible Securities and Stock Purchase Warrants, 2 Rocky MT. L. REv. 16 (1929).

10 All anti-dilution clauses provide for appropriate and obvious adjustments to take account of splits and combinations of the underlying shares. 
conversion price, distributions of stock dividends, extraordinary dividends in cash or kind, issuance of options, and corporate mergers or consolidations. The lawyer must also deal with the problem of whether the conversion price should escalate at specific intervals as an inducement for conversion and the possibility of the corporation's evasion of the anti-dilution provisions.

These problems would be easier to handle if there were an underlying theory for the clause. However, it is difficult to formulate a theory and to reconcile the provisions of many clauses with any single theory. A generally accepted description of the purposes of the clause might be the following: "The purpose of anti-dilution provisions is, of course, to provide for adjustment in the amount of securities to be issued upon conversion of a convertible security ... in order to compensate for certain changes affecting the security ... into which it is convertible."11 Such a definition does not, however, give any indication of which "changes affecting the security" should trigger an adjustment, nor does it indicate the nature of the adjustment which such changes should occasion. Stating that the objective of the clause is to protect the right of conversion is even less helpful since it does not identify the theory of the clause or the threats against which it is to guard the convertible security holder. Another way of defining the fundamental theory of the anti-dilution clause is to say that it is drawn to protect against any change in the exchange ratio, that is, to insure that the percentage of the total number of underlying shares deliverable on exercise of the right of conversion will remain unchanged, despite alterations in the corporate structure, except as otherwise provided in the anti-dilution clause. Another possible theory is that it protects against a change in the value of the securities deliverable upon exercise of conversion. This is undoubtedly too broad and comprehensive a statement of purpose, because there are doubtless many events and occurrences of a business or economic nature which may materially and adversely affect the value of the underlying security which do not cause an adjustment of the conversion price. ${ }^{12}$ It is also possible to contend that one of the purposes of the anti-dilution clause is to protect the market value of the underlying security against a decline arising from modification of the corporation's capital structure. Though a portion of the customary anti-dilution clause can seemingly be explained only by such a theory, that theory will not provide explanation or justifica-

11 Irvine, supra note 9 , at 729 .

12 Furthermore, this theory fails to jibe with the fact that the conversion privilege enhances the value of the senior security by permitting the senior security holder to share in the growth of the corporation by converting to the junior security. 
tion for the bulk of the contents of a customary anti-dilution clause. Of the several theories described above it is probable that the protection of the exchange ratio, in a broad and loose sense, is the most likely general underlying basis for the customary anti-dilution clause, although some specific provisions of the customary clause may well be difficult to reconcile with such a theory. Possibly a cumulation of these suggested explanatory theories may underlie the clause, with the holder of the convertible security getting the benefit of any protective provisions suggested by any or all of the several theories. ${ }^{13}$

\section{A. Sale of Common Stock Below the Specified Conversion Price}

The conversion price is the agreed upon price at which each share of the underlying security is to be obtained upon conversion. If new shares of the underlying security are issued at a price less than the conversion price ${ }^{\mathbf{1 4}}$ and if no adjustment is made in the rights of the convertible security holder, the value of shares obtained upon conversion will be diluted.

Three of the four types of anti-dilution clauses adopt the same fundamental approach to the problem; these three clauses are here termed "traditional" or "customary." The last type of clause is a new and radical challenger, departing sharply from the others in this regard.

The earlier anti-dilution clauses often provided that the number of underlying shares deliverable upon conversion would be protected against dilution by a direct adjustment of the number of shares deliverable. If the arrangement were to deliver one share of common stock upon conversion of - one share of the convertible security, the ratio would be one to one, and the early adjustment provisions would have specified a direct change in that ratio. Although the effect remains fundamentally the same, current anti-dilution clauses achieve their results by a method which is slightly indirect but which is simpler in operation. Current clauses provide that the conversion shall be made at a rate determined by a conversion price and that any variations in the conversion price caused by operation of the anti-dilution clause will in turn vary the number of underlying shares deliverable upon conversion. Thus, if the basic arrangement was to deliver one share

13 The purpose of the traditional anti-dilution clause may be obscured because the clause has grown by what Mr. Justice Cardozo called the "agglutinative" process, in which each newly drafted clause not only reproduces the last available previous form but also includes a new provision to deal with any additional contingency which has occurred to the draftsman.

14 This may take place by stock dividend (which is an issuance of shares without consideration), public sale or private placement of underlying shares at a price below conversion price, issuance of underlying shares for property worth less than the conversion price, or an offering to shareholders below the conversion price. 
of common stock upon conversion of one share of preferred stock and if the original conversion price was $\$ 100$, then a five for one common stock split will cause the new conversion price to drop to $\$ 20$ and five common shares will be deliverable upon conversion of one share of the preferred stock. This change in the conversion price is a computation device designed only to facilitate determining the number of underlying shares deliverable upon conversion. It is, however, in such general use that the "conversion price" method has practically supplanted the older "conversion rate" method and is the central characteristic of the traditional anti-dilution clause mechanism.

The first type of anti-dilution clause reduces the conversion price to the lowest level at which the issuer sold the underlying stock in any sale not specially excluded from consideration. ${ }^{15}$ This is the most favorable clause for the convertible security holder and the harshest clause for the junior security holder. It deprives the issuing corporation of necessary flexibility in its financial affairs and is probably obsolete at present, since it could only be achieved or imposed by an unusually dominant investor.

A second traditional type of anti-dilution clause deals with the sale of underlying shares at a price below the original conversion price by reducing the conversion price to the weighted average of the price of any underlying securities sold below the conversion price and the conversion price then in effect. This clause, however, does not allow any adjustment upward in the event of the sale of underlying securities at a price in excess of the original or the current conversion price. For convenience, this type of anti-dilution clause, which until recently was the most popular, will be characterized as the "downward conversion price clause." The pertinent portion of a typical downward conversion price clause provides:

... In case the Company shall at any time or from time to time after May 31, 1954 issue or sell any of its Common Shares

15 Most anti-dilution clauses permit certain kinds of issuances of underlying stock without adjustment of the shares deliverable upon conversion. Presumably these transactions are exempted because they are either inherently beneficial to the enterprise or else because their exemption is specifically negotiated and bargained for. Alternatively, it has been suggested that the purchaser of the convertible security takes the situation as he finds it with the exceptions representing potential risks of dilution he has already assumed. The exclusions most frequently found are (1) shares deliverable against restricted stock options (usually with a maximum number specified), (2) treasury shares (sometimes limited to shares to be acquired for the treasury in the future and not extending the exemption to treasury shares already held), (3) shares deliverable upon conversion of the outstanding convertible securities, (4) shares in a prescribed amount which may be issued in a single underwriting or private placement for a specific purpose, and (5), stock dividends of a specified character or amount. 
... for a consideration per share less than the conversion price in effect immediately prior to the time of such issue or sale, said conversion price then in effect and the conversion price or prices then applicable for any subsequent period or periods shall be adjusted ... to a price (calculated to the nearest cent) determined by dividing (i) an amount equal to the sum of (x) the number of Common Shares outstanding immediately prior to such issue or sale multiplied by the then existing conversion price, and (y) the consideration, if any, received by the Company upon such issues or sale by (ii) the total number of Common Shares outstanding immediately after such issue or sale. ${ }^{16}$

The downward conversion price clause was generally popular in the financings of the 1920's and 1930's but after World War II, when there was a great expansion of financing through convertible securities, many issuers argued that if the holders of underlying securities were to be penalized by a reduction in the conversion price when the issuer sold underlying securities below the conversion price, some equivalent allowance should be made when the issuer sold underlying securities at a price in excess of the conversion price. These contentions revolved about the drafting of anti-dilution clauses which provided for an offsetting adjustment of the conversion price to reflect sales of underlying securities at prices above the then effective conversion price, but with a ceiling on the upward adjustment fixed at the initial conversion price. ${ }^{17}$ For example, an initial conversion price of $\$ 10$ would be unaffected by a subsequent sale of securities at $\$ 12$ per share, but if the initial conversion price had been lowered by subsequent sales below $\$ 10$, another sale at $\$ 12$ would raise the conversion price, but not over the original conversion price of $\$ 10$. In most clauses of this "two-way

16 The provision has been reproduced from an actual instrument, with only irrelevant and identifying matter delęted. Copy on file at The University of Chicago Law Review office. Other illustrations of clauses and provisions will be similarly set forth throughout this article. The following is an example of a computation in accordance with this type of provision:

If $P$ is the conversion price, $X$ is the number of shares outstanding prior to the new issuance, $N$ is the number of new shares to be issued and $Y$ is the consideration for which they are to be issued, then $C P$, the new conversion price, can be found by the following formula: $\frac{\mathrm{PX}+\mathrm{NY}}{\mathrm{X}+\mathrm{N}}=\mathrm{CP}$. Translated into numbers, if $P$ is $\$ 10,1000$ shares are outstanding, and an additional 1000 shares are to be issued at $\$ 5$, the formula would read as follows:

$$
\frac{10 \times 1000+5 \times 1000}{1000+1000}=\$ 7.50 \text {, the new conversion price. }
$$

I7 It might be argued that the ceiling of the initial conversion price should not be imposed; however, I have never seen an anti-dilution clause which contained a different ceiling figure. 
conversion price" type, whether the decrease in conversion price will be offset by increases in the value of underlying shares due to sales above the conversion price depends upon whether the sales above the conversion price precede the sales below the conversion price. However, there is no reason why the downward adjustment in conversion price should not be offset in the event of a sale of underlying shares above the current conversion price regardless of when that sale occurred.

The anti-dilution clause providing for upward adjustment is sometimes called the "current quotient formula," but might better be referred to as the "two-way conversion price clause."18 An example of this type of clause is as follows:

(1) In case the conversion price in effect immediately prior to the close of business on any day shall exceed by 50 cents or more the amount determined at the close of business on such day by dividing:

(i) a sum equal to (a) ( $x$ ) (being the total number of shares of Common Stock outstanding at the date of this Indenture) multiplied by $\$(y)$ (being the initial conversion price), plus (b) the aggregate of the amounts of all consideration received by the Company upon the issuance of Additional Shares of Common Stock (as hereinafter defined), minus (c) the aggregate of the amounts of all dividends and other distributions which shall have been paid or made after the date of this Indenture on Common Stock of the Company, other than in cash out of its earned surplus or in Common Stock of the Company, by

(ii) the sum of (a) (z) (being the total number of shares of Common Stock outstanding at the date of this Indenture) and (b) the number of Additional Shares of Common Stock which shall have been issued, the conversion price shall be

18 The current quotient formula is described in Irvine, Some Comments Regarding "Anti-dilution" Provisions Applicable to Convertible Securities, 13 Bus. LAw. 729, 730 (1958):

Under the formula in its simplest form, the current quotient is the decimal equivalent of a fraction which may be expressed as $\frac{A B+C}{A+D}$ where $A$ is the num-

ber of shares outstanding at the time of issuance of the convertible debentures, $B$ is the initial conversion price, $\mathrm{C}$ is the aggregate consideration received for all additional shares of common stock issued subsequent to the issuance of the debentures, and $D$ is the total number of such additional shares. If the conversion price in effect at the close of business on any day exceeds the current quotient determined immediately after the close of business on each day, the conversion price is reduced to the current quotient so determined, the adjustment being effective as of the opening of business on the next succeeding day.

The argument for the right to average in sales above conversion price as well as those below it appears to have carried the day; it well may be that the downward conversion price formula has been largely superseded by the current quotient and may soon be replaced by a genuine two-way adjustment conversion price formula. 
reduced, effective immediately prior to the opening of business on the next succeeding day, by an amount equal to the largest integral multiple of 50 cents contained in the amount by which such conversion price shall exceed the amount so determined. ${ }^{19}$

It should be noted that this clause provides only for reduction in price. Thus, if the conversion price has been reduced, a subsequent sale will not raise it. If, however, there has been a sale at a price above the initial conversion price, that sale will tend to offset a subsequent sale below the initial conversion price.

A small number of investment bankers have recently given currency to a radically different type of anti-dilution clause, denominated a "market price" clause. Although this type of clause was used, I have been informed, as far back as the 1920's, it has only recently received wider application. ${ }^{20}$ It is primarily distinguished from the traditional conversion price clauses in that it adjusts the conversion price in connection with the sale of underlying shares by the issuing company only when such sale is made to the company's common shareholders in a rights offering at a price below the then current market price for such shares, without regard for the conversion price. ${ }^{21}$

19 A fully flexible two-way adjustment formula follows: If $P$ is the initial conversion price, $O$ is the number of shares outstanding at the time of the issuance of the convertible securities, $C$ is the aggregate consideration received for all additional shares of underlying securities issued subsequent to the issuance of the convertible securities and $A$ is the total number of such additional shares, $C P$ (the new conversion price) can be ascertained by the following formula:

$$
\mathrm{CP}=\frac{(\mathrm{O} \times \mathrm{P})+\mathrm{C}}{\mathrm{O}+\mathrm{A}}
$$

Translated into numerical terms in a simple example, if the initial conversion price was $\$ 10$ and 1000 shares were outstanding at the time of the issuance of convertible securities and if two additional issues of new shares in the amount of 500 shares each at prices of $\$ 5$ and $\$ 15$ respectively had been made, then the new conversion price would be ascertained (whether it raises or lowers the current price) as follows:

$$
\frac{10 \times 1000+5 \times 500+15 \times 500}{1000+1000}=\$ 10,
$$

which is the newest conversion price.

20 It is to be found in the securities issues underwritten by Goldman, Sachs \& Co. and Kidder Peabody \& Co.; it is also used by Equitable Life Assurance Society.

21 An adherent of the market price form of anti-dilution provision stated in a letter to me the theories for the market price and the conversion price forms as follows:

"Market Price." An adjustment based upon sales below the market price (whether above or below the conversion price) is designed to protect the current market value of the conversion privilege as it exists from time to time.

"Conversion Price." An adjustment based upon sales below the conversion price is designed to preserve the intrinsic value of the conversion privilege as it existed at the time of the issuance of the convertible security, determined on the assumption that the underlying security had at that time a potential value at least equal to the original conversion price.

Letter on file in The University of Chicago Law Review office. He then proceeded to 


\section{B. Stock Dividends}

Stock dividends have presented a thorny problem for drafters and interpreters of anti-dilution clauses. If a stock dividend amounts to a substantial percentage of the outstanding shares it is probably a means of splitting the stock and is generally treated as an issuance of stock without consideration requiring an appropriate downward adjustment of the conversion price. If, however, the stock dividend supplements or substitutes for the issuing company's cash dividends, there is often great uncertainty as to the proper application of antidilution clauses, which do not expressly deal with the problem. The dispute over the treatment of stock dividends involves a conflict between economic realities and the literal terms of the anti-dilution clause.

For example, a corporation might announce that it will conserve cash for internal development by substituting stock dividends of $\$ 5$ market value for its $\$ 5$ annual cash dividend. The stock dividend obviously increases the number of outstanding shares without raising any money for the corporation. Over a period of years these periodic distributions could be the equivalent of a single $50 \%$ stock dividend which would require an appropriate adjustment in the amount of securities deliverable upon conversion. However, it can be argued that since the stock dividend is only a substitute for a cash dividend which would not affect the conversion ratio, the stock dividends also should not require an adjustment of the conversion ratio. Moreover, the corporation could issue the stock dividends without any adjustment of the conversion ratio by paying the $\$ 5$ cash dividend and then selling its shareholders stock in an amount equal to the cash dividend declared. Although in the absence of a specific provision dealing with this question the parties will usually agree to adjust the conversion ratios if the stock dividend is large, it is becoming common to include specific provisions which exempt from the operation of the anti-dilution clause those dividends which are merely substitutes for cash dividends. Perhaps a more specific and safer provision would require, as a condition for exemption, that the company's cash dividends shall be at or below an agreed level per annum instead of merely setting a maximum limit upon stock dividends which shall not affect the conversion price and stipulating that the stock dividend be issued in

describe an additional kind of anti-dilution clause which combines both the market price and the conversion price form of clause, the theory of which he described as follows: "'Combination of Market Price and Conversion Price.' A provision combining the conversion price and market price clauses to provide whichever adjustment shall be the greater is designed to protect both the current market value of the conversion privilege and its original intrinsic value." 
substitution for cash distributions. This would more clearly preclude the issuer from doubling its distribution by giving both cash and stock dividends. $^{22}$

\section{G. "Capital" Distributions}

Controlled events or capital rearrangements voluntarily and deliberately effected by management may properly warrant "semi-punitive" downward adjustment of the conversion price. Suppose that the company increases its cash dividend policy on underlying shares from its long standing practice of a $5 \%$ annual dividend to $10 \%$ per annum. Or suppose the company decides to distribute its surplus among holders of its underlying shares by making an extraordinary cash distribution equivalent to ten or twenty times its customary annual dividend. Or suppose the issuing company declares a partial liquidating dividend. Should such events trigger an adjustment of conversion price? Because they would affect the market value of the shares and the worth of the conversion privilege, they should probably be specially provided for as events causing readjustment of conversion price. Occasionally antidilution clauses provide for adjustment upon such events. ${ }^{23}$ Other

22 The treatment of stock dividends for the purposes of anti-dilution clauses raises problems similar to those met when such dividends are allocated between income and principal or between life tenant and remainderman for trust administration purposes. There has been very little theoretical consideration of whether "regular" dividends declared in stock should be treated as income or principal, or may be allocated partly to one and partly to the other. See 2 Scorr, Trusts $\$ 236.7$ (1939). Extraordinary stock dividends have been treated differently and irreconcilably in many jurisdictions. See $i d$. at $\$ 236.3$. But under \& 5(I) of the widely adopted Uniform Principal and Income Act all dividends payable in shares of the corporation are to be deemed principal. By analogy, all dividends in stock should be regarded as dilution and should therefore occasion modification of the conversion price. Hence, if it is desired to prevent such modification should regular stock dividends be declared in lieu of cash dividends, the burden should properly be upon the drafter of the anti-dilution clause to make an express provision to that effect.

23 A typical provision of this type reads as follows:

Other Dividends and Distributions, Except Certain Warrants or Other Rights or Convertible Securities. In case after the date hereof the Company shall take a record of the holders of its Common Stock for the purpose of entitling them to receive any dividend or other distribution of

(1) cash (other than a cash distribution made as a dividend and payable out of earnings or earned surplus legally available for the payment of dividends under the laws of the jurisdiction of incorporation of the Company, to the extent, but only to the extent, that the aggregate of all such cash dividends paid or declared after the date hereof does not exceed the net income of the Company earned subsequent to the date hereof, determined in accordance with sound accounting practice), or

(2) any evidences of its indebtedness (other than Convertible Securities), any shares of its stock (other than Additional Shares of Common Stock) or any other securities or property of any nature whatsoever (other than cash), or

(3) any warrants or other rights to subscribe for or purchase any evidences of its indebtedness (other than Convertible Securities), any shares of its stock (other than Additional Shares of Common Stock) or any other securities or property of any nature whatsoever,

then the number of shares of Common Stock thereafter comprising a Stock Unit shall be adjusted to that number determined by multiplying the number of shares 
clauses provide that upon the extraordinary events described therein, which would include an unusual cash dividend or a dividend in kind, the holders of convertible securities shall be entitled to receive appropriate notice-possibly thirty to sixty days-of the proposed dividend or other prescribed event, so that they may convert and thereby receive the benefit of such distribution. If they fail to convert, the distribution is permitted to be made without any adjustment in the conversion price. ${ }^{24}$ The rationale of such a notice provision is that the convertible

of Common Stock comprising a Stock Unit immediately prior to such adjustment by a fraction (i) the numerator of which shall be the Current Market Price per share of Common Stock at the date of taking such record, and (ii) the denominator of which shall be such Current Market Price per share less the portion applicable to one share of Common Stock of any such cash so distributable and of the fair value (as determined in good faith by the Board of Directors of the Company) of any and all such evidences of indebtedness, shares of stock, other securities or property, or warrants or other subscription or purchase rights, so distributable. A reclassification of the Common Stock into shares of Common Stock and shares of any other class of stock shall be deemed a distribution by the Company to the holders of its Common Stock of such shares of such other class of stock within the meaning of this Subsection and, if the outstanding shares of Common Stock shall be changed into a larger or smaller number of shares of Common Stock as a part of such reclassification, shall be deemed a subdivision or combination, as the case may be, of the outstanding shares of Common Stock within the meaning of Subsection $A$ of this Section.

Copy on file in The University of Chicago Law Review office.

24 The following is a typical "notice" provision:

Notice of Certain Corporate Action. In case the Company shall propose (a) to pay any dividend payable in stock of any class to the holders of its Common Stock or to make any other distribution to the holders of its Common Stock (other than a cash dividend payable out of earnings or earned surplus legally available for the payment of dividends under the laws of the jurisdiction of incorporation of the Company, to the extent, but only to the extent, that the aggregate of all such cash dividends paid or declared after the date hereof does not exceed the net income of the Company earned subsequent to the date hereof, determined in accordance with sound accounting practice), or (b) to offer to the holders of its Common Stock rights to subscribe for or to purchase any Additional Shares of Common Stock or shares of stock of any class or any other securities, rights or options, or (c) to effect any reclassification of its Common Stock (other than a reclassification involving only the subdivision or combination of outstanding shares of Common Stock), or (d) to effect any capital reorganization, or (e) to effect any consolidation, merger or sale, transfer or other disposition of all or substantially all of its property, assets or business, or ( $f$ ) to effect the liquidation, dissolution or winding up of the Company, then, in each such case, the Company shall deliver to the Warrant Agent notice of such proposed action, which shall specify the date on which a record is to be taken for the purposes of such stock dividend, distribution of rights, or the date on which such reclassification, reorganization, consolidation, merger, sale, transfer, disposition, liquidation, dissolution, or winding up is to take place and the date of participation therein by the holders of Common Stock, if any such date is to be fixed, and shall also set forth such facts with respect thereto as shall be reasonably necessary to indicate the effect of such action on the Common Stock and the number and kind of any other shares of stock which will comprise a Stock Unit, and the purchase price or prices thereof, after giving effect to any adjustment which will be required as a result of such action, and shall cause copies of such notice to be mailed (by first class mail postage prepaid) to each holder of a Warrant at his last address as shown on the books of the Company maintained by the Warrant Agent. Such notice shall be so delivered and mailed in the case of any action covered by Clause (a) or (b) above at least 20 days prior to the record date for determining holders of the Common Stock for purposes of such action, and in the case of any other such action, at least 20 days prior to the date of the taking of such proposed action or the date of participation therein by the holders of Common Stock, whichever shall be earlier.

Copy on file in The University of Chicago Law Review office. 
security holders have been given an opportunity to share in the benefits of such an unusual event and that if they fail to take advantage of the opportunity they should no longer be accorded any further protection against this type of contingency. However, in effect this shortens the period during which the holder of the convertible security may retain his option to convert at the same value ratios and subjects him to forced conversion upon such events instead of preserving his conversion right through the adjustment machinery of the anti-dilution clause.

\section{Issuance of Options, Rights, Warrants and Convertible Securities}

Another type of corporate action which gives great difficulty and is variously handled in anti-dilution clauses is the issuance of options, rights, warrants or other convertible securities ${ }^{25}$ calling for the delivery of underlying shares at a price lower than the specified conversion price. Some anti-dilution clauses make no adjustment of the conversion price until the underlying shares are actually issued; they are then treated as stock sold below the conversion price with the price received upon their issuance being the aggregate of the initial option cost, if any, plus the exercise price subsequently received. Other anti-dilution clauses recognize the fact that the issuance of such calls adversely affects the market for underlying securities by creating the possibility that additional underlying shares will be issued at a reduced price; the potential existence of a large block of lower priced shares overhanging the market constitutes a threat to the existing price of the underlying shares and often causes it to be reduced.

Consequently, partly to discourage the issuance of such calls upon underlying shares at reduced prices and partly to provide for appropriate adjustment in conversion price, many anti-dilution clauses provide that the issuance of such calls shall be treated, for purposes of adjusting the conversion price, as if the underlying shares involved had immediately been issued at the exercise price stipulated in the call. It is generally provided that if the calls expire without being exercised there shall be a corresponding readjustment to nullify the prior adjustment. The mere issuance of calls could injure the convertible security holder by adversely affecting the market price of the underlying securities and, correspondingly, of the convertible securities. Such an immediate conversion price adjustment upon the issuance of the calls is almost the only provision in the customary anti-dilution clause which depends upon market price effect as its justification.

25 Options, rights to purchase stock, stock warrants, and other classes of convertible securities all have a similar effect for purposes of possible dilution in connection with convertible securities. Unless otherwise indicated by the context, they will all, in the interest of brevity, be referred to as "calls." 
The issuance of such calls, although they may affect the market, will not have as significant or as large a dilutionary effect as the actual exercise of the call at the lower price. Although the provision for an adjustment upon the issuance of a call and a later reverse readjustment if it is not exercised is designed to protect the convertible security holder from the dilution discussed above, it also may give rise to anomalous and sometimes unfair effects. Let us suppose that in the event of the issuance of a large block of calls at $50 \%$ of the current conversion price, the particular clause in question provides that the conversion price will immediately be adjusted downward. If the holder of the convertible security thereupon converts at the lowered conversion price and the call subsequently expires without exercise, the convertible security holder has been granted a windfall at the expense of the underlying shareholder by receiving additional shares through an adjustment based on a contingency which did not occur. On the other hand, a convertible holder who delays his conversion until the call has been exercised will receive an increased number of underlying shares and a convertible holder who waits until the call has expired without exercise will not receive any increase in the number of underlying shares whose market price has presumably been unaffected by the issuance of the call. An anti-dilution clause which would prevent this kind of unfairness, though excessively complicated, might provide that the conversion price be adjusted upon the issuance of the call, with the additional shares prescribed by this change in the conversion price being held in escrow to be delivered upon the exercise of the call but to be cancelled in the event it expired without exercise. This would grant the convertible security holder protection against the change in market price during the period when the call was outstanding but would prevent him from receiving the windfall represented by an adjustment against a sale of shares which never occurred. ${ }^{26}$

26 A related problem, which arises particularly in connection with single options or single warrants to purchase substantial numbers of shares, is whether a reduction in price pursuant to an anti-dilution clause is the only remedy which the holder of the convertible security or the call is entitled to have. If, for example, the anti-dilution clause provides that the issuance of a certain number of shares at a price below the conversion price shall cause a downward adjustment in the price at which the option or call is exercisable, and such an issuance does in fact trigger the price reduction, is the purchaser entitled not only to buy the underlying shares at the adjusted price but also to purchase an increased number of shares at the adjusted price sufficient to let the purchaser continue to buy a stipulated portion of the outstanding shares equivalent to the proportion which he would have had had there not been additional issuance of shares which triggered off the price reduction? In other words, does the holder of such an instrument bargain not only for a reduced price but also for something analogous to preemptive rights which enable him to maintain a specific proportion of the shares of the company if he exercises this right to purchase? 


\section{E. Mergers}

Another situation which the cutomary anti-dilution clause does not handle effectively is the combination of one corporation with another where convertible securities are outstanding. These combinations have become increasingly frequent and more important in recent years. The customary clause usually provides in general terms that the right of conversion shall be protected in the event of such combination. This works suitably if the corporation which has issued convertible securities is merged into a corporation which has outstanding only common stock or several classes of nonconvertible stock. It also works suitably if the issuing corporation is the surviving corporation in a merger with a corporation that has no convertible securities and no unusual classes of securities senior to its common shares. However, where the terms of a merger provide, for example, that the holders of convertible securities shall receive a new security with a modified conversion privilege or where the other corporation party to the combination has outstanding convertible securities which have a different conversion price, the effectiveness of the standard clause is open to question. Probably the only way that such a clause can operate effectively is by requiring the parties to a combination to work out in good faith a new arrangement which makes appropriate adjustments. However, in the more involved forms of corporate combination, such as the sale of $40 \%$ of the assets of Corporation $A$ to Corporation $B$ for common stock of $B$ followed by the merger of Corporation $A$ into Corporation $C$, the ordinary "boilerplate" merger provisions of an anti-dilution clause amount to little more than the convertible's prayer for fair play. Perhaps a court would intervene to prevent gross injustice, but the clause is usually so general in the face of so many possible variations of corporate combination that it does not yield predictable results and in fact is often irrelevant. It might be worthwhile, when drafting such a clause, to provide that any questions of the application of the anti-dilution clause upon merger, consolidation or sale of any substantial portion of the assets shall be referred for arbitration to a stipulated person or institution who is given binding authority to make the necessary readjustments. Otherwise, the problems of drafting a merger provision sufficiently comprehensive to deal with the manifold variations in corporate combinations are almost impossible to cope with, except by providing that the parties shall agree in the future upon "fair" adjustments. Of course, the convertible security holders may elect to convert before the merger takes place and thus assure that they will be treated similarly to the holders of the underlying securities. 


\section{F. Escalation}

Many anti-dilution clauses, in order to induce conversion, provide that the conversion price shall escalate at specific intervals. For example, an initial price of $\$ 10$ may rise to $\$ 12$ at the end of five years and $\$ 14$ at the end of another five years. This type of simple increase can lead to problems if there has been any adjustment in conversion price during the prior period as when the initial conversion price is reduced in the fourth year from $\$ 10$ to $\$ 8$. An automatic increase at the end of the fifth year to $\$ 12$ would result in a $\$ 4$ increase instead of the $\$ 2$ increase intended. Consequently, it is better to provide that escalation shall be made by the addition of a specified number of dollars to the conversion price in effect at the time when escalation occurs instead of specifying the new conversion price as an absolute figure to come into effect at a given moment. Perhaps a better way of dealing with this problem would be to add to the adjusted conversion price then in effect a proportionate increase which bears to the adjusted price the same ratio as the stipulated increase bore to the original price, thus preserving the original proportion arrangements. This preserves for the convertible security holder the full benefit of any downward adjustments in the conversion price.

\section{G. Evasion}

None of the types of anti-dilution clauses, whether constructed on the conversion price or the market value formula, is impervious to evasion. If a corporation which has convertible securities outstanding chooses deliberately to benefit the common shareholders and to undermine the worth of the conversion privilege, there is at least one method which avoids any adjustment under either the traditional or the market price clause. The corporation can authorize an intermediate class of shares, junior to the outstanding convertible securities but with full preference rights over the underlying common shares so that they could not be considered common shares. Such intermediate shares could be endowed with an abnormally high dividend rate and could then be issued on preemptive rights to common shareholders at an extremely attractive price. Because they would not be "underlying" shares, their issuance would not trigger the anti-dilution clause. However, the heavy diversion of earnings to the intermediate shares would diminish the value of the underlying shares, to the detriment of the holders of convertible securities but not to the detriment of the holders of common stock who would have bought the new shares on a favorable basis.

It is conceivable that some liberal and forward-looking court might 
enjoin the issuance of such intermediate shares at the instance of a convertible security holder on the ground that the sale price of the newly issued shares was grossly disproportionate to intrinsic value. But this is highly unlikely since the common shareholders would have no objection to the sale. Moreover, such action would have to be based on the common law rather than on an express provision of the antidilution clause. Some measure of protection against this kind of evasion might be afforded by a provision in an anti-dilution clause requiring that the holders of convertible securities be given notice of any corporate action which adversely affects the securities deliverable upon conversion. Thus the holders of convertible securities could effect conversion prior to the effective date of such adverse action. Occasionally, an anti-dilution clause contains a catch-all provision to the effect that, if any corporate action shall be taken which has not been dealt with specifically in the anti-dilution clause but which has an adverse effect upon the right of conversion, some appropriate adjustment as determined by an independent firm of attorneys or accountants shall be made in the conversion price. It would seem clearly desirable from the convertible security holder's viewpoint that a provision of this general nature be included in anti-dilution clauses more frequently or indeed that it become standard "boilerplate" in such clauses. ${ }^{27}$

27 For example:

In case at any time or from time to time conditions arise by reason of action taken by the Company, which in the opinion of the Board of Directors, are not adequately covered by the provisions of this Article Four, and which might materially and adversely affect the conversion rights of the Debenture holders, the Board of Directors shall appoint a firm of independent certified public accountants of recognized standing, who may be the firm regularly retained by the Company, who shall give their opinion upon the adjustment, if any, on a basis consistent with the standards established in the other provisions of this Article Four, necessary with respect to the Conversion Price, so as to preserve, without dilution, the conversion rights of the Debenture holders. Upon receipt of such opinion, the Board of Directors shall forthwith make the adjustments described therein.

Copy on file in The University of Chicago Law Review office. Would not a more suitably objective approach be to have the accountants described in the above section appointed by the trustee or by a specified percentage of security holders rather than by the board of directors of the company? The clause might also call for an adjustment in conversion price whenever a corporate action through readjustment of capital or issuance of new shares modifies the rights of common shareholders to participate or share in the earnings of the company.

It is probably accurate to say that the desire to participate in the earnings of the company and to maintain a specified ratio of participation in earnings is the prime motivation for the convertible security holder's investment and the primary reason behind the anti-dilution clause. It could be argued that the major purpose of the anti-dilution clause is not only to guard the ratio of shares delivered but more importantly to assure an anticipated participation in earnings; therefore, the possibility that an intermediate class of diversionary preferred stock will be inserted or that similar insidious devices will be used should be forestalled by a general provision for adjustments in conversion ratio upon any change in the ratio of participation in earnings by the underlying shares deliverable 
As a matter of remedy, the interposition of an intermediate class of preferred stock with characteristics designed to circumvent the purposes of the anti-dilution clause might possibly be attacked by the convertible security holder through an action under that increasingly ubiquitous panacea, rule $10 \mathrm{~b}-5,{ }^{28}$ on the ground that such conduct constitutes a "scheme to defraud ... in connection with the ... sale of securities." This possibility is worthy of cognizance because there is an offering of shares pursuant to preemptive rights and hence a "sale" of securities. However, it is extremely doubtful whether the courts would or should apply rule $10 \mathrm{~b}-5$ to such a situation, particularly because the convertible security holder would be neither a purchaser nor a seller of the intermediate class of securities, and also because there would be no reliance upon a fraudulent misrepresentation. ${ }^{29}$

upon conversion. If conversion price adjustment were geared only into earnings participation to protect against interposing an intermediate class of securities with an inordinate participation in earnings, a similar type of evasion could be attempted by giving a normal share in earnings to the newly created intermediate class of securities, with exaggerated voting rights or an overly generous treatment upon liquidation or upon merger or consolidation. Consequently, it would seem that the better way to deal with the possibility of the insertion of an intermediate class of securities would be pursuant to some general treatment rather than merely by gearing adjustment into inroads upon earnings.

2817 C.F.R. $\S 240.10 \mathrm{~b}-5$ (1949), promulgated by authority of $\S 10(\mathrm{~b})$ of the Securities Exchange Act of 1934, 48 Stat. 891 (1934), 15 U.S.C. \$ 78j(b) (1964).

20 In addition to the importance to this problem of $\S 10(\mathrm{~b})$, there are also a number of complex problems of liability under $\& 16(\mathrm{~b})$ of the Securities Exchange Act of 1934 which grow out of the question whether conversion of a convertible security is an outright sale or a purchase of the security deliverable upon such conversion under the meaning of § 16(b). See, e.g., Heli-Coil Corp. v. Webster, 222 F. Supp. 831 (D.N.J. 1963), rev'd in part, 34 U.S.L. WeEK 2192 (3d Cir. Oct. 1, 1965); 19 Rutgers L. Rev. 151 (1964). See generally 2 Loss, Securities Regulation 1066-75 (2d ed. 1961). As an example of the oblique way in which the impact of the anti-dilution clause is likely to be felt, see Blau v. Lamb, $242 \mathrm{~F}$. Supp. 151 (S.D.N.Y. 1965), appeal docketed, No. 29940, 2d Cir., Aug. 13, 1965, where liability was asserted against an insider under $\S 16(\mathrm{~b})$ on the ground that the insider had first exchanged his shares of common stock in another corporation for convertible preferred stock of the issuing corporation and within six months after the first exchange had converted his preferred stock into common stock. The court held that the initial exchange of another corporation's common stock for the issuing corporation's convertible preferred was a purchase of the latter and also that the conversion of the preferred stock into common stock was a sale of the preferred and a purchase of the common. The court therefore imposed liability upon the insider. In connection with the anti-dilution clause the court stated:

Throughout the protracted history of this litigation, the defendants have emphasized the importance of the provision in the preferred certificates which, like a similar provision attaching to the Ashland Oil securities, protected the preferred against the diluting effect of any possible split or stock dividend on the common stock by providing for a proportionate adjustment in the conversion rate. Thus, defendants argue, the Air-Way preferred was the economic equivalent of the Air-Way common, and the conversion of the preferred did not interrupt the continuity of their investment in Air-Way-i.e., the disposition of the preferred by conversion did not constitute a "sale."

The simple answer to this argument is this anti-dilution feature did not place the holder of preferred stock in precisely the same investment position as the 


\section{Comparison of the Market Price Cilause and Traditional Glauses}

The basic tenet of the market price clause is that the holder of the convertible security should be treated, for purposes of protection against dilution, as if he were a common shareholder. Thus, this anti-dilution clause adjusts for splits, combinations, and major stock dividends but does not adjust for sales of common stock below conversion price unless the sales confer a benefit upon the common shareholders by giving them stock below the market price. The sale price's relationship to conversion price is immaterial.

As an example of the significant difference between the operations of the two clauses consider a situation in which a security holder has 100 shares of convertible preferred stock which are convertible into 100 shares of common stock at $\$ 10$ a share. If the issuing corporation sells to the public another block of common shares equal in number to the total outstanding shares at the time of the issuance of the convertible preferred stock and at the present market price of $\$ 8$ per share, the market price clause will make no adjustment and the 100 shares of convertible preferred stock will continue to be convertible into 100 shares of common stock. Under the traditional conversion price clause the conversion price will, on the same set of facts, drop from $\$ 10$ a share to $\$ 9$ a share, an average between the initial conversion price and the new sales price of $\$ 8$ per share, and the 100 shares of convertible preferred stock will then be convertible into approximately 111 shares of common stock. Assuming conversion, there will be an $11 \%$ difference in the operation of the two clauses. This, not an extreme example, illustrates the results produced by the two types of clauses in a frequently recurring situation; such variation in results may justify a price differential and certainly justifies a clear description in the market analysis bulletins and prospectuses.

holder of common stock. On the contrary, by conversion, Lamb and Enterprises significantly enhanced their investment position in three important respects:

(1) greater voting power, (2) greater dividends and (3) greater marketability of their shares .....

On the other hand, in apparent contradiction of his counsel's argument that the preferred was the economic equivalent of the common, Lamb testified upon cross examination that, although he knew he was giving up valuable preferences when he converted, "... I felt I should have the same status as the other stockholders ...."

Thus, irrespective of the anti-dilution feature of the preferred, the latter was simply not the economic equivalent of the common stock. By converting the preferred, Lamb and Enterprises received a totally different security with an attendant alteration in the risks and advantages involved. To put this another way, conversion into common stock required an investment decision based upon wholly different considerations than those involved in the decision to exchange for the preferred stock. 242 F. Supp. at 157-58. 
An underlying assumption of the market value approach is that any sale of common stock for less than market value will probably be a sale for a good business purpose and one in which the interests of the holders of common shares and of convertible securities will be identical. ${ }^{30}$ If the company needs additional cash and it is necessary to sell common shares to persons other than present common shareholders at a disadvantageous price, such a course, it is contended, is for the benefit of the entire enterprise. Hence common and convertible securities holders should receive equal treatment. The market price clause thus recognizes the economic realities which require securities to be sold on the best terms possible under the particular business conditions then applicable and does not deter a company from necessary financing by the sale of common stock when the market price is below the conversion price. Unlike the traditional clause, it does not subject the issuer to the unfavorable effect on financing terms caused by downward adjustment of the conversion price and the consequent possibility that the value of the underlying shares will decrease at some future time through conversion at the reduced conversion price.

The clause drafted pursuant to the market price formula is simpler than the traditional clauses, its proponents contend, and has the advantage of dealing with normal, expectable corporate transactions; any improper conduct or abnormal activity will be prevented by the prohibitions of corporation statutes or by fiduciary restraints under the common law or securities regulations statutes. ${ }^{31}$

30 In a letter to the writer, one of the leading investment banks which has adopted the market price formula anti-dilution clause stated its reasons as follows:

Briefiy, we consider the market price form of anti-dilution clause more realistic than the conversion price formula as it more closely parallels the protection available to the common stockholder, which the holder of convertible securities has the right to become.

If the company sells additional common stock at a price below the market a common stockholder who usually has a pre-emptive right to participate in the sale, may avoid dilution of his investment by either exercising his rights or selling them. No such avenue is, of course, open to the holder of a convertible security. However, a similar type of protection may be given him by providing that the cost of the common stock which he has the right to acquire be adjusted in line with the discount for market at which the new shares were sold. We feel that this type of adjustment is more meaningful than adjusting for the sale of stock below the conversion price.

Letter on file in The University of Chicago Law Review office.

31 The reasons supporting use of the market price formula in preference to the conversion price formula were set out in a letter from an eminent New York attorney:

Goldman Sachs has for many years prided itself on the shortness and succinctness of its prospectuses and financial documents, believing that this leads to easier understanding by the investing public and more careful consideration of the significance of each provision. Consequently, one of the criteria was to make the statement of the formula as short as possible but at the same time to retain the real and practical protections considered necessary. For this reason many of the contingencies covered in great detail in other statements of anti-dilution formulas, 
Although there is much cogency in the arguments of the proponents of the market price formula, a number of problems are raised. First, the assumption basic to the market price clause that common and convertible shareholders should bear equal risks arguably fails to recognize the nature of the convertible security and the basis upon which it is purchased and traded in the financial community. Many, if not most, convertible securities have temporally limited conversion rights, even further limited by escalating prices during the lifetime of such rights. In the case of the convertible debt security, the right terminates on the maturity date of the security. In the case of convertible stocks, the right of conversion is often limited to a period of years and is seldom in effect for the entire period during which the stock may be outstanding. The right is also generally subject to the time limitation growing out of the power of the issuing company to retire or force conversion of the convertible security. Consequently, it may be argued that the holder of convertible securities is more likely to have a short-run con-

but which are less likely to arise as a practical matter, are left to the protection of basic corporate law or to good faith valuations by the board of directors. An example of this is that no specific provision is made for an adjustment in the event of the sale of common stock for less than the current market price to others than stockholders. Such a sale would lay the directors open to a charge of waste of corporate assets and, therefore, as a practical matter, such a sale is not likely to occur. Furthermore, this would also dilute the existing common stock holders, who presumably elected the directors, and to whom the directors are answerable. In other words, the interests of the holder of the conversion feature and the holder of common stock are the same.

The market price formula and the conversion price formula are based on two entirely different underlying theories. The market price formula is fundamentally based upon the concept that the holder of the convertible security, in so far as his conversion feature is concerned, is in the same position as a common stockholder. In other words, if the common stockholders receive a benefit, this should be reflected in the formula. If, on the other hand, the corporate action or recapitalization is at the expense of the common stockholder, then the stock issuable upon conversion should bear its share of that expense. To express it more simply, when the value of the common stock has been lowered by a benefit received by the common stockholders, the conversion price should be adjusted. Consequently, there is no dilution adjustment on the issue of additional common stock (other than by way of split ups, stock dividends, etc.) unless the additional issue has been offered to the common stockholders at a price less than its current market value. In this event the formula is calculated to decrease the conversion price in the proportion that the market value of the stock "cum rights" bears to the market value of the stock "ex rights."

On the other hand, the underlying theory in the conversion price formula is that the holder of the convertible security, irrespective of changes in the affairs of the corporation or the market, is guaranteed an adjustment in the conversion price whenever common stock is issued for a consideration below the conversion price and this is true whether or not any benefits were received by the common stockholders. In other words, as far as the conversion feature is concerned, he is better off than, not just equal to, a holder of common stock. The adjusted conversion price under this formula is calculated by multiplying the number of common shares previously outstanding by the conversion price, then adding the value received for the additional shares issued and dividing that sum by the number of shares then outstanding. Usually an adjustment is made only if the conversion price would thereby be decreased. However, in some instances the formula has provided for adjustments in the case of increases but this is not true in many cases.

Letter on file in The University of Chicago Law Review office. 
cept of his investment than is the common stockholder; hence it may not be sufficient or appropriate to regard him as a common stockholder or to put him in a position where his interest can be diluted merely because of a price change in the stock market.

Second, if there is any misconduct of the kind which this clause leaves to be guarded by the restraints of general corporate law, it is not always certain that the holder of convertible securities will be in a position to institute a suit to enjoin such misconduct or to reverse it. For instance, if the complainant holds convertible debt securities, is he entitled to enforce corporate restraints generally thought to be designed for the benefit of shareholders only? If he holds convertible preferred shares, can he bring a derivative suit to restrain a corporate wrong currently affecting only common shareholders, or must he bring an action for damages in which he must bear the difficult burden of showing individual harm?

Third, the difficult problem of proving a deviation from market price in sales to common shareholders, which would be necessary for the convertible security holder to protect himself in a disputed situation, is a deterrent to suits under the market price clause. Assuming that all questions of standing to sue have been resolved in favor of the holder of convertible securities and that he wishes to challenge the fairness of the price, the burden would lie upon such holder either to enjoin an issuance of the underlying stock at a proposed price which is allegedly below the market or to obtain a judicial declaration that a sale of underlying stock previously made had actually been made at a price below market, and therefore that the conversion price should be revised. In the case of the small closed or private corporations, where convertible securities are often used as a means of obtaining senior investment capital, proving whether a sale is at or below market would be almost impossible. due to the nonexistence of any real market with respect to the securities of such a corporation. Therefore, the market price clause will probably find little or no acceptance in the convertible securities issued by small or closed corporations or by corporations whose outstanding securities have a limited market. Problems of proving market price of securities traded over the counter would also be far from inconsequential. Securities in the over-thecounter market tend to trade with a substantial difference between the bid and the asked. What then is the appropriate market price for the purposes of this anti-dilution clause: the bid price; the asked price; the price at which securities are actually traded, if that is ascertainable; or the mean between the bid and the asked? In the absence of a specific provision in the anti-dilution clause, any choice from these alternatives 
would be arbitrary. Even with respect to securities listed on a national securities exchange, the market price clause must still define when the market price is relevant to the clause. Even given a date, the price for a listed security might be the opening price for the day, the closing price, the day's high, or the day's low. Presumably the purpose of the market value clause is to provide a price which is unaffected by the price at which the stock is to be offered to stockholders in the rights offering. If this is the case, then the market price must be taken at a time before there has been any announcement of the rights offering price. However, any person experienced in corporate finance will recognize that the actual announcement of the price of a rights offering will almost always be preceded by speculation and discussion of probable price and may often be preceded by "leaks," intentional or inevitable, with respect to the price. Hence, the selection of a truly unaffected trading period and market price will be quite difficult.

Fourth, the market price clause deprives the convertible security holder of some windfalls, in the form of increased amounts of shares deliverable upon conversion, which have been built into the traditional conversion price clauses. It might be urged that the investor in convertible securities, who is seeking the best of both possible worlds of security and equity growth, has come to expect these "traditional" boons and that this expectation is reflected in the market prices of convertible securities. ${ }^{32}$ Whether such implicit understandings should be lightly abandoned without fanfare or public notice raises questions of propriety and fairness.

However difficult may be the problems of computing market price in connection with sales of common stock to present common stockholders, it must further be remembered that the price at which common stock is sold to persons other than present common stockholders in a rights offering does not occasion an adjustment of conversion price under the market price formula, regardless of the price at which such a sale takes place. ${ }^{33}$ It is possible that a sale proposed, without pre-

32 It should be noted that there is one rare circumstance under which the market price clause will produce benefits for holders of the convertible securities which would not be obtainable under the standard conversion price clause. Under most conversion price antidilution clauses a sale of underlying stock above initial conversion price but below market price will have no effect on future conversion price or the number of shares deliverable upon conversion. However, under the market price clause, if the issuer sells underlying stock to present stockholders at a price above the initial conversion price but below the then current market price the conversion price will be adjusted by increasing the number of shares deliverable upon conversion.

33 It must be recognized that corporations sometimes sell securities to outsiders at unfavorable prices for various reasons in connection with issuances of stock for property, attempts to affect control, and various kinds of private placements. 
emptive rights for present stockholders, at a price deemed unfairly low might be enjoined as inequitable. ${ }^{34}$ However, this possibility of dilution requires the holders of convertible securities to be vigilant in advance of such sales so that they may block them by injunction. Such vigilance must be of an extraordinary degree since ordinary corporate formalities do not require that advance notice of such sales be given to the holders of convertible securities, particularly debt securities, unless the anti-dilution clause expressly so provides.

Moreover, the possibility of defeating in whole or in part the effective protection of the market price clause might be open to any management which wished unscrupulously to further the interests of the common stockholders as against those- of the convertible security holders; since the board of directors probably regards itself as representing the common stockholders, the inducement to evade or avoid the restrictions of the anti-dilution clause in favor of the common stockholders is always very great. ${ }^{35}$ Let us suppose, for example, that the conversion price, as well as the market price of underlying common shares, is $\$ 10$ a share. The directors cut the dividend on the stock by $50 \%$; the market price then drops from $\$ 10$ to $\$ 8$. The directors make a stock offering upon rights to the present shareholders at the new market price of $\$ 8$; in the following year the dividend is restored to its prior level and the market price returns to $\$ 10$. The outcome of this series of events is an actual dilution. By lowering the dividend, with its predictable market consequences, the representatives of the common shareholders can reduce the price for which they can sell shares to common shareholders without a corresponding adjustment in the conversion price. It can, of course, be argued that a maneuver done for the purpose of authorizing a sale at a reduced market price in order to obviate the impact of the anti-dilution clause should be vulnerable to legal attack. However, the problem of proving that the dividend was reduced solely for the purpose of creating a false market and evading the impact of the anti-dilution clause would be extremely difficult. The likelihood of success in a suit by holders of the convertible securities would probably be very slight in view of the roster of corporate purposes which any astute board of directors could muster to show the need for conserving cash and the courts' general unwillingness to scrutinize carefully directors' business purposes. ${ }^{36}$

34 Cf. Bodell v. Grand Gas \& Elec. Corp., 15 Del. Ch. 119, 131, 132 Atl. 442, 447 (Ch. 1926) (dictum), aff'd, 15 Del. Ch. 420, 140 Atl. 264 (Sup. Ct. 1927).

35 See, e.g., Goldman v. Postal Tel., Inc., 52 F. Supp. 763 (D. Del. 1943).

36 See, e.g., Barnes v. Andrews, 298 Fed. 614 (S.D.N.Y. 1924); Burkhart v. Smith, 161 Md. 398, 157 Atl. 299 (1931); Ucello v. Golden Foods, Inc., 325 Mass. 319, 90 N.E.2d 530 (1950); Murphy v. Hanlon, 322 Mass. 683, 686, 79 N.E.2d 292, 293-94 (1948). 
Similarly, without revision of the conversion price a board of directors might be able to take advantage of fortuitous temporary market dips to favor common shareholders. For example, the board of directors of a company which had an especially fine earnings record and extraordinary prospects could have decided during a market decline following such an event as President Eisenhower's heart attack or President Kennedy's assassination that the cause of the major market drop was temporary in effect. The board might then make an offering of common stock to common stockholders at the new low prices during the period of the depressed market. When the market price is restored after an interval of market adjustment, the net result would be dilution of the convertible security holder's interests against which anti-dilution clauses are normally expected to protect. Of course, it may be said that the willingness of the common shareholders to gamble upon the return of the market to its previous level is an act of faith or good judgment in the face of uncertainty which merits financial reward. However, the risk borne by the common stockholders is minimal in the case of a general but foreseeable temporary market retreat caused by an occurrence extrinsic to the internal affairs of the issuing corporation.

Drafters of the market price clauses are cognizant of these possibilities of maneuver and by the definition of market price contained in their clauses have sought to block some of the obvious loopholes. The following is typical of such provisions:

For the purpose of any computation ... the current market price per share of Common Stock at any date shall be deemed to be the average of the daily closing prices for the thirty consecutive business days commencing forty-five business days before the day in question. The closing price for each day shall be the last reported sales price regular way, or, in case no such reported sale takes place on such day, the average of the reported closing bid and asked prices regular way, in either case on the New York Stock Exchange, or, if the Common Stock is not listed or admitted to trading on such Exchange, on the principal national securities exchange on which the Common Stock is listed or admitted to trading, or if not listed or admitted to trading on any national securities exchange, the average of the closing bid and asked prices as furnished by any New York Stock Exchange firm selected from time to time by the Company for the purpose.

However, such a clause does not resolve the problem of the absence of any market for the stock of the closed corporation nor does it suc- 
cessfully prevent the company from causing the market price to be reduced by dividend cuts or other action of similar impact. It merely prevents the company from using a very temporary change in market price as the basis of an offering price to shareholders; even in such a situation it should be noted that the temporarily reduced price during the computation period will have the effect of depressing the average price used for the anti-dilution clause. Moreover, this provision leaves unsolved the problem of the appropriate price to stockholders when the price of the issuers' stock is sharply rising. Since the quoted formula is computed on market performance for the average of the thirty days preceding fifteen days before the date of the sale to common shareholders, in a rapidly rising stock market such a computation could work serious injustice on the holders of convertible securities merely by reason of the price lag.

One would think, in light of these difficulties, that a convertible security which contains a traditional conversion price clause should be of greater value to the convertible security holder and should accordingly sell at a higher price than a comparable convertible security containing a market price clause. ${ }^{37}$ Such a price differential should follow

37 Similarly, the prospectuses used to describe sales of convertible securities which have different types of anti-dilution clauses should clearly differ from one another. At present prospectuses for convertible securities generally include, at best, cryptic statements which reveal the differences between anti-dilution clauses only if read with care and penetration by financially sophisticated purchasers. For an example of a description of anti-dilution provisions see the following statement in the prospectus relating to $4 \%$ convertible subordinated debentures of Celanese Corporation of America dated March 17, 1965, at page 20, on file in The University of Chicago Law Review office:

Such conversion price is subject to adjustment under a formula in certain events, including issuance of Common Stock for a consideration less than the conversion price, Common Stock dividends amounting to $5 \%$ or less of the outstanding shares, and other dividends not in cash out of earned surplus (with credit under the formula for sales of Common Stock above the conversion price) and is subject to automatic proportionate adjustment if the Common Stock is subdivided or combined or in case of Common Stock dividends of more than $5 \%$. Even this description is more extensive and specific than is customarily found in prospectuses. See note 6 supra and accompanying text. Compare with this a prospectus filed with the Secretary of State of Canada in accordance with the provisions of the Companies Act of Canada and not to be used in connection with offerings in the United States. That prospetcus states: "The indenture pursuant to which the convertible debentures 1989 series will be issued includes provisions for adjustment of the conversion privilege in certain events." In the body of the prospectus it also states, at greater length than is customary in the United States:

The 1964 supplemental debenture indenture contains provisions to the effect that, in the event of (a) any reduction in the number of common shares of the company due to consolidation thereof, or (b) any increase in the number of such common shares outstanding due to subdivision thereof, a proportionate adjustment shall be made in the number of common shares of the company issuable pursuant to such conversion privilege subsequent to any such change in the number of outstanding common shares becoming effective. The 1964 supplemental debenture indenture also contains other provisions to the effect that if the company at any time after September 3, 1964, issues or sells (with certain exceptions set forth 
even if, as contended by proponents of the market price clause, such a clause is sounder, more realistic and more desirable. So far as I am able to ascertain, there are no statistics available which indicate the comparable prices of convertible securities containing these different kinds of clauses; however, the result of inquiries made to date leads me to believe that the market does not draw any sophisticated price distinctions between convertible securities based upon differences in the type of anti-dilution clause which the securities contain. This leads me to infer not only that the general investing public has failed to realize that there is any distinction between the various types of clauses but also that most persons in the investment business are either unaware of the distinction or attribute no practical significance to it. ${ }^{38}$

\begin{abstract}
in the 1964 supplemental debenture indenture) common shares at a price different from the conversion price in effect immediately prior to the issuance of such common shares, or issues any common shares on the exercise of rights to sub. scribe for or warrants to purchase common shares, or of any options for the purchase of common shares or on conversion of any securities (other than convertible debentures 1988 series and the convertible income notes) (convertible into or exchangeable for common shares) and the consideration per share for which common shares were issued pursuant to such rights, warrants, options or convertible or exchangeable securities is in any case less than the said conversion price in effect immediately prior to the issuance of such common shares, the conversion price referred to shall be adjusted (in the manner set forth in the 1964 supplemental debenture indenture) so as to protect the conversion privilege of the convertible debentures 1989 series against dilution.
\end{abstract}

Copy on file in The University of Chicago Law Review office. The anti-dilution clause to which the Canadian prospectus refers substantially follows the form of the customary conversion price formula commonly in use in the United States.

Contrast with the above a clause contained in a prospectus which refers to a market price anti-dilution clause as follows:

The conversion rate is subject to adjustment on certain events, including the issuance of stock of the company as a stock dividend; subdivisions, combinations and reclassifications of the Company's Common Stock; the issuance to holders of Common Stock of rights or warrants to subscribe for Common Stock at less than the current market price as defined for the purpose; or the distribution to holders of Common Stock of evidences of indebtedness, assets (excluding cash dividends to the extent permitted by Section 4.6 of the indenture summarized above under "certain restrictions"), a right to subscribe other than those mentioned above.

Copy on file in The University of Chicago Law Review office.

38 The following excerpt from a letter written by a large and presumably knowledgeable purchaser of securities who specializes in convertibles affords an example of market reaction; even less awareness of differences between such clauses can be inferred on the part of less sophisticated professional securities dealers and certainly in the case of nonprofessional investors:

This is in answer to your letter of January 18, 1965, regarding our practices and views on the anti-dilution clauses of convertible securities. We do not make any precise market adjustment because of anti-dilution clauses, i.e. no formula is used, but we do take such clauses into account in determining the attractiveness of the security.

Basically what we expect from an anti-dilution clause is to allow the convertible holder to participate with the common shareholder in any adjustments that would affect a shareholder of common stock. Generally such adjustments would be the same as those that would result in a change in the per share tax cost basis as determined for Federal Income Tax purposes. (While there is no direct 


\section{Conclusion}

The anti-dilution clause is an integral and necessary part of any convertible security. The clause is a complex, difficult and intriguing exercise in corporate draftsmanship. It requires the draftsman to protect against the whole gamut of potential corporate rearrangement or manipulation which might adversely affect the rights of the holders of the convertible securities. So intricate and precise an instrument should be prepared with the greatest care and diligence.

There is great variance among the different types of anti-dilution clauses now in use. Some are prepared on the basis of terms imposed by the investor in convertible securities, so as to provide him with the utmost advantage which can be exacted under the circumstances. Other anti-dilution clauses are intentionally lenient, to minimize the issuers' burden of conversion as much as possible. Still other anti-dilution clauses attempt an evenhanded compromise of the different possible positions. There seems to be no really consistent theoretical thread running through these clauses that is based upon a single enunciated basic principle or objective. If, for example, the clause is designed to protect the market value of the securities deliverable upon exercise, it is inadequately and incompletely effected. To speak of protecting the right of conversion begs the question; in the absence of a precise theory one cannot know precisely what the "right of conversion" entails.

The market price theory comes closest to providing a coherent and consistent theory for the drafting of anti-dilution clauses. However, at least in public issues of securities, this theory entails so great a modification of the rights traditionally accorded to the convertible security holder by the usual conversion price anti-dilution clause that the value of the security itself should be affected. The symmetry of the market price theory does not necessarily outweigh the desirability of adjusting the conversion price upon the issuance of common stock below conversion price; refraining from adjustment in such a contingency deprives the convertible security holder of the benefit of the protection

relationship between tax costs and anti-dilution clauses, the philosophy behind determining adjustments to either one would appear to be the same.) ....

You mention that Goldman Sachs and some other underwriters are taking the position that the anti-dilution clauses should not include adjustments for sale of common stock below the conversion price. Although as a buyer of convertible securities I would like to receive every possible benefit, I fail to see the logical reasoning for an adjustment in such cases. Such sales do not create anything of value that the common shareholder may dispose of so that under the philosophy of "riding along with the shareholder" the bondholder should probably not benefit when the common shareholder does not. The bondholder would presume that the offering of stock is being made for the general good of the company and all its shareholders.

Letter on file in The University of Chicago Law Review office. 
against the risks assumed by the common shareholder admittedly provided by the traditional conversion price clause. If it can be said that an investor in convertible securities bargains for immunity against those very risks and for a conversion price which guarantees a particular ratio upon conversion of the common stock, then he is entitled to be protected against the very vicissitudes which the market price type of clause imposes upon him.

It is essential that the parties to the transaction be aware of the numerous possibilities open to the draftsman of the anti-dilution clause if the resultant bargain, whatever its final form, is to be an informed one. The terms of the anti-dilution clause must be recognized as significant and, above all, as negotiable. ${ }^{39}$

38 See, for a most interesting report on the American Bar Foundation's endeavors in this area, Rogers, The Corporate Trust Indenture Project, 20 Bus. LAw. 551, 562 (1965). The basic objective of the project appears to have been the preparation of "boilerplate" sections of a corporate trust indenture which could be incorporated by reference into a shorter instrument which embodies the particular negotiated terms of a specific deal. $I d$. at 562 ("The first task is to separate the boilerplate from the negotiable provisions."). The project found that while some provisions were clearly negotiable and others were clearly standard boilerplate, many others occupied an uncertain status in between. $I d$. at 563. Interestingly, an early version of the Model Provision contained a boilerplate antidilution clause which was not contained in the final draft. Under the analysis advanced in this article it is apparent that anti-dilution clauses should be classified as negotiable; hence I am pleased to see that the Model Provisions in their final form do not treat them as standard. 